\title{
Lipid Oxidation: The Role of Aframomum danielli Antioxidant Extracts in Prevention
}

\author{
Etti, C. $\mathrm{J}^{1}$, Adegoke, G. $\mathrm{O}^{2}$, and Etti, I. $\mathrm{C}^{1}$ \\ ${ }^{1,3}$ Department of Agricultural and Food Engineering, Faculty of Engineering, University of Uyo, Akwa Ibom \\ State, Nigeria \\ ${ }^{2}$ Department of Food Technology, University of Ibadan, Nigeria
}

\begin{abstract}
The effects of Aframomum danielli (A. danielli) anti-oxidant extract on lipid oxidation was studied. Mayonnaise samples were treated with antioxidant extracts and the anti-oxidant activities of A. danielli extracts from three different solvents; ethanol, $n$-hexane and diethyl ether and that of synthetic antioxidant butylated hydroxyl anisole (BHA) were evaluated using chemical parameters like peroxide value, $\mathrm{pH}$ and free fatty acid value. The mayonnaise sample treated with 200ppm concentration of the diethyl ether antioxidant extract of A. danielli was the best active in the control of lipid oxidation in mayonnaise with values of $0.40 \%$ free fatty acid (FFA), $2.60 \mathrm{mEq} / \mathrm{kg}$ peroxide value (PV) and $6.35 \mathrm{pH}$ compared to synthetic antioxidant butylated hydroxyl anisole (BHA) with values of $0.80 \% \mathrm{FFA}, 3.00 \mathrm{mEq} / \mathrm{kg} P V$ and $6.50 \mathrm{pH}$. The percentage antioxidant effectiveness on the $60^{\text {th }}$ day of mayonnaise storage has shown A. danielli antioxidant extract (200ppm) concentration from diethyl ether, ethanol and n-hexane to be $83.30 \%, 80.33 \%$ and $78.72 \%$ respectively compared to $76.56 \%$ antioxidant efficiency of BHA making A. danielli extracts to be preferable to synthetic antioxidant extract BHA in the control of lipid oxidation in mayonnaise.
\end{abstract}

Keywords: Antioxidant activity, Aframomum danielli extracts, Mayonnaise, Lipid oxidation

\section{Introduction}

Peroxidation in a membrane or a system containing polyunsaturated fatty acids is due to the attack of a peroxyl radical species which is capable of abstracting a hydrogen atom from a methylene group [1]. Oxidative deterioration of polyunsaturated lipids always result in a problem known as rancidity in food stuffs (e.g. mayonnaise, margarine and cooking oils) [2]. In cell membranes, lipid peroxidation causes the membrane to become less "fluid" with increasing loss of membrane integrity allowing ions such as $\mathrm{Ca}^{2+}$, which do not normally cross the membrane to do so [1]. Oxygen free radicals (OFR) play a significant role in the pathogenesis of many diseases like atherosclerosis, cancer, neuro-degeneration and inflammation [3]. Free radicals are produced endogenously during cellular metabolism and their production may be greatly enhanced by exogenous factors such as environmental pollutants, radiations, pathogens and metal ions[4][5]

Many synthetic chemicals such as BHA and butylated hydroxyl toluene (BHT), though very effective as antioxidants, have been known to have toxic and carcinogenic effects on humans [6][3]. Numerous studies have shown the antioxidant potentials of aromatic spices and medicinal plants [7][8][9]. The use of these plant materials as natural antioxidants for food, cosmetics and other applications become necessary because of food safety issues [6]. Natural antioxidant are being used as food additives for inactivation of free radicals because of their scavenging properties and are readily acceptable by consumers [10]. Different degrees of antioxidant activities have been reported from extracts of spices and herbs.

Aframomum danielli is a local spice found in tropical Africa. The spice has been reported to exhibit antioxidant properties in different oil systems[11][12]. This spice has been found to have preservative property in some food systems[13]. This study is therefore aimed at evaluating the antioxidant potential of A. danielli extracts from different solvents and that of synthetic antioxidant BHA in mayonnaise product.

\section{Materials And Methodology}

Aframomum danielli spices were obtained from Bode market, Ibadan, Nigeria. Ingredients for mayonnaise were obtained from Bodija market in Ibadan, Nigeria.

\subsection{Spice Preparation:}

The seeds of A. danielli were removed from the pods of the fruit and were cleaned of all extraneous materials and adhering particles. The seeds were air dried at $27 \pm 2^{\circ} \mathrm{C}$ for 3 days due to its low moisture of about $10.9 \%$ determined by [14]. The seeds were then pulverized into a tiny powdery formin a hammer mill after drying and it was stored at $4^{\circ} \mathrm{C}$ until it was used. 


\subsection{Solvent extraction of A.danielli spice:}

The method described by [7] was used for solvent extraction of A. danielli spice. 500ml each of diethyl ether solvent, ethanol solvent and $\mathrm{n}$-hexane solvent was used to extract finely ground A. danielli spice under refluxing condition for 10 hours respectively. The filtrate of each extraction was freed of the solvent to recover the extract by evaporation of the solvent. The filtrate which was the spice extract was packaged and kept at $4^{\circ} \mathrm{C}$ until it was used.

\subsection{Production of Mayonnaise:}

This was done according to the method described by [15]. 10.80g of egg yolk was mixed thoroughly with dissolved salt $1.50 \mathrm{~g}$, Sugar $2.50 \mathrm{~g}$, cinnamon $0.20 \mathrm{~g}$ and vinegar $10.80 \mathrm{~g}$ for about $2-3$ minutes in a laboratory mixer( Kenwood Cheff model). Oil (soybean oil) was slowly added to the mixture to form an emulsion as the mixing proceeded. The addition of oil lasted for about 15 minutes. $10-15 \%$ of the oil was added slowly during the first five minutes of the mixing and $50 \%$ of the oil was added during the next five minutes of the mixing and then the remaining $35-40 \%$ of the oil was added gradually during the last five minutes of the mixing. After the production of the mayonnaise, it was packaged in transparent plastic materials, sealed and stored at room temperature.

\subsection{Antioxidant Incorporation}

The antioxidant extract of A. danielli spice extracted with diethyl ether, ethanol and $n$-hexane solvents were incorporated into different samples of prepared mayonnaise at $200 \mathrm{ppm}$ concentration by direct addition using the method of [16]. Synthetic antioxidant BHA was also incorporated into another mayonnaise sample at 200ppm concentration also using [16] method. Control sample which was a sample with no antioxidant extract was also obtained. Chemical tests were carried out on the five samples of mayonnaise.

\subsection{Peroxide value $(\mathrm{PV})$}

Peroxide value was determined by titrimetric method of [17]. $1 \mathrm{~g}$ of the mayonnaise sample was weighed into a clean dry boiling tube to which $1 \mathrm{~g}$ of powdered potassium iodide and 20mlmixture of glacial acetic acid and chloroform in the ratio 2:1 were added. The tube was held in boiling water for 30 seconds after which the contents were transferred into a $250 \mathrm{ml}$ conical flask containing $20 \mathrm{ml}$ of $5 \%$ potassium iodide solution. This was titrated against $0.002 \mathrm{~m}$ sodium thiosulphate solution using $1 \mathrm{ml}$ of starch as indicator. A blank titration (without any sample) was also made and the results were reported as the number of $0.002 \mathrm{~m}$ sodium thiosulphate per gram of sample.:

Peroxide value $=\frac{(V-V o) T}{M} \times 10^{2}(\mathrm{mEq} / \mathrm{kg})(1)$

Where $v=$ Titre value of sample, $v_{o}=$ Titre value of blank, $\mathrm{T}=$ molarity of sodium thiosulphate and $M=$ mass of fat (gram)

\section{$2.6 \mathrm{pH}$}

$\mathrm{pH}$ was estimated using the method described by [14] and $\mathrm{pH}$ was measured directly using Corning $220 \mathrm{pH}$ meter. The $\mathrm{pH}$ of the samples were measured with electrode standardized using $\mathrm{pH} 4$ and $\mathrm{pH} 7$ buffer solution

\subsection{Free fatty acid (FFA)}

The FFA was determined by titrimetric method of[14]. Mixture of $25 \mathrm{ml}$ diethyl ether, $25 \mathrm{ml}$ alcohol and phenolphthalein solution $(1 \%)$ was carefully neutralized with $0.1 \mathrm{~m}$ sodium hydroxide. $1 \mathrm{~g}$ of the mayonnaise sample was dissolved in the mixed neutral solution and was titrated with aqueous $0.1 \mathrm{~m}$ sodium hydroxide. The mixture was shaken constantly until a pink colour that persisted for 15 seconds was obtained.:

$$
\text { Acid value }=\frac{\text { Titration }(\mathrm{ml}) \times 5.61}{\text { WtofSampleused }}(2)
$$

\subsection{Determination of Antioxidant effectiveness}

The percentage antioxidant effectiveness during storage test period was monitored using the method described by[18].:

Antioxidanteffectiveness $=\frac{\text { PVofcontrol }- \text { PVoftestsample }}{\text { PVofcontrol }} \times 100(3)$ 
III. Result And Discussion

Table 1: Physical characteristics of A. danielli fruits

\begin{tabular}{ll}
\hline Fruits & Characteristics \\
\hline Botanical Name & Aframomum danielli \\
Yoruba Name & Atare oboro \\
Family & Zingiberaceae \\
Shape & Oblong \\
Colour of seed & Reddish brown \\
Appearance of seed & Shiny \\
Average weight of fruit & $2.76 \mathrm{~g}$ to $3.10 \mathrm{~g}$ \\
Percentage filled of seeds in the fruit & $60.8 \%$ to $66.3 \%$ \\
Colour of the antioxidant extracts & Brownish black liquid with \\
& thick viscosity \\
\hline
\end{tabular}

Table 2: Yield of A. danielli Antioxidant Extracts

\begin{tabular}{lllll}
\hline solvent & $\begin{array}{l}\text { Vol. of } \\
\text { solvent } \\
\text { used } \\
(\boldsymbol{m} \boldsymbol{l})\end{array}$ & $\begin{array}{l}\text { Quantity of } \\
\boldsymbol{A} \text {. danielli } \\
\text { powder used }(\mathrm{g})\end{array}$ & $\begin{array}{l}\text { Yields of } \boldsymbol{A} . \\
\text { danielli } \\
\text { extracts }(\mathrm{g})\end{array}$ & $\begin{array}{l}\text { (\%) yield of } \boldsymbol{A} . \\
\text { danielli extracts }\end{array}$ \\
\hline Diethyl ether & 500 & 85 & 11.11 & 13.07 \\
Ethanol & 500 & 92 & 11.87 & 12.90 \\
n-hexane & 500 & 85 & 9.31 & 10.95 \\
\hline
\end{tabular}

Table 3: Antioxidant effectiveness of extracts on mayonnaise samples

\begin{tabular}{lllll}
\hline Samples & $\begin{array}{l}\text { Antioxidant effectiveness } \\
\text { (\%) at day 20 }\end{array}$ & $\begin{array}{l}\text { Antioxidant effectiveness } \\
\text { (\%) at day 40 }\end{array}$ & $\begin{array}{l}\text { Antioxidant } \\
\text { effectiveness } \\
\text { day 60 }\end{array}$ & (\%) at \\
\hline A & 60.61 & 77.24 & 83.30 \\
B & 59.09 & 74.80 & 80.33 & \\
C & 56.06 & 72.68 & 78.72 \\
D & 54.55 & 71.54 & 76.56 & \\
E & Control & & & \\
\hline
\end{tabular}

Key:

$\mathrm{A}=$ mayonnaise sample treated with extracts of $A$. danielli from diethyl ether solvent

$\mathrm{B}=$ mayonnaise sample treated with extracts of $A$. danielli from ethanol solvent

$\mathrm{C}=$ mayonnaise sample treated with extracts of $A$. danielli from $\mathrm{n}$-hexane solvent

$\mathrm{D}=$ mayonnaise sample treated with synthetic antioxidant BHA

$\mathrm{E}=$ mayonnaise sample treated with no antioxidant (Control)

figure 1: Peroxide values of mayonnaise treated with antioxidant extract 
figure 2: Free fatty contents of Mayonnaise treated with antioxidant extracts

Generally, antioxidants are widely used to prevent lipid oxidation in processed foods, raw materials or fats and oils based foods[19]. The potency of the antioxidant is aimed at preventing or delaying rancidity in foods.

\subsection{Peroxide Value}

The peroxide value is a measure of the peroxides contained in the oil. Peroxides are primary reaction products formed in the initial stages of oxidation, and therefore give an indication of the progress of lipid oxidation [17]. During storage, peroxide formation is slow at first during an induction period that varies with time and temperature of the environment.

From Fig. 1, the highest increase in peroxide value was found in the control sample E, this was because there was no antioxidant extract incorporation into the sample. This result confirms the result of [20] on their study on the use of antioxidants to minimize rancidity in pressurized cooked chickens slurries, their results showed that samples with rosemary extracts had effects on their pressurized samples compared to samples without any antioxidants. Sample "A" which was sample of mayonnaise with extracts of A. danielli from diethyl ether solvent was the least and the best in terms of peroxide value as shown in Fig. 1. It means that lipid oxidation was slowest in this sample due to the work of the antioxidant, it could also be stated that diethyl ether solvent was able to extract the active component from A. danielli that was responsible for the work of antioxidization in mayonnaise. This further confirms the fact that natural antioxidants are better antioxidant agents compared to synthetic antioxidant BHA in this case (sample D) [21].

Table 4: Changes in $\mathrm{pH}$ of mayonnaise samples after 60days

\begin{tabular}{llll}
\hline Sample & pH initial & pH after 60 days & Decrease in $\boldsymbol{p H}$ \\
\hline A & 6.35 & 6.30 & 0.05 \\
B & 6.40 & 6.30 & 0.10 \\
C & 6.70 & 6.36 & 0.34 \\
D & 6.50 & 6.30 & 0.20 \\
E & 7.10 & 5.54 & 1.56 \\
\hline
\end{tabular}

\section{$3.2 \mathrm{pH}$}

From table 4, the $\mathrm{pH}$ of all the samples decreased or tended towards acidic region. The reduction in $\mathrm{pH}$ of the samples indicates microbial and enzymatic activities during the storage of the samples and thus resulted in the production of acidic compounds. The decrease in $\mathrm{pH}$ was highest in the control sample (E), because there was no antioxidant to control or Inhibit the activity of enzymes and microorganisms.

Sample A, extracts of $A$. danielli antioxidant using diethyl ether solvent had the least decrease in $\mathrm{pH}$ showing that microbial and enzymatic activity was really slowed in this sample compared to synthetic antioxidant which was sample $\mathrm{D}$, this also confirms the facts that natural antioxidants possess antimicrobial activity[22].

\subsection{Free fatty acid (FFA)}

From Fig. 2, the changes in FFA of mayonnaise samples during sixty (60) days of storage can be seen. Increase in FFA was highest in sample E and least in sample A. the order of increase was as follows: sample E > sample D > sample B > sample C > sample A. Rancidity is often accompanied by FFA formation, it means that 
Sample A was able to inhibit the formation of FFA better than the other samples, this further confirms the fact that diethyl ether extracts of $A$. danielli antioxidant was able to retard lipid oxidation better than synthetic antioxidant BHA (sample D) and other extracts [21].

\subsection{Antioxidant Effectiveness}

Table 3 shows the results of antioxidant effectiveness of extracts on mayonnaise samples during the 60 days of storage. The antioxidant effectiveness increased with increase in days of storage. Sample A had the highest antioxidant efficiency $(83.30 \%)$ compared to synthetic antioxidant sample D with BHA $(76.56 \%)$ antioxidant efficiency. This further confirms that natural antioxidants are better substitute to synthetic antioxidants in the control of lipid oxidation [23].

\section{Conclusion}

The result of this study has shown that at 200ppm concentration, Aframomum danielli antioxidant extracts can be used to reduce lipid oxidation in mayonnaise thereby extending the shelf life of the product. It was also seen that natural antioxidant (A. danielli) is better than synthetic antioxidant (BHA) in inhibiting lipid oxidation in mayonnaise.

\section{References}

[1] B. Halliwell and J. M. C. Gutteridge, Free Radicals in Biology and Medicine. Oxford: Clarendon Press, 1985.

[2] E. N. Frankel, "In search of better methods to evaluate natural antioxidants and oxidative stability in food lipids," Trend Food Sci. Technol., vol. 4, pp. 220-224, 1993.

[3] N. Ito, S. Fukushima, A. Hasegawa, M. Shibata, and T. Ogiso, "Carcinogenicity of butylated hydroxyanisole in F 344 rats," J. Natl Cancer Int., vol. 70, pp. 343-347, 1985.

[4] S. Das, S. Vasisht, D. Snelhata, N. Das, and L. Srivastava, "Correlation between total antioxidant status and lipid peroxidation in hypercholesterolemia," Current Science, vol. 78, p. 4, 2000.

[5] O. R. Fennema, Food Chemistry, 2nd edn. New York: Marcel Dekker, 1985, pp. 96-145.

[6] S. B. Fasoyiro, G. O. Adegoke, and O. O. Idowu, "Characterization and partial purification and antioxidant component of Ethereal factors of Aframomum danielli," World Jounal of Chemistry, vol. 1, pp. 1-5, 2006.

[7] S. S. Chang, M. B. Ostic, O. Q. Hseih, and C. L. Huang, "Natural antioxidant from rosemary and sage," J. Food Sci, vol. 42, pp. 1102-1106, 1977.

[8] T. Osawa, K. Hirotak, H. Hagiwara, and T. Shibamoto, "A novel antioxidant isolated from young green barley leaves," J. Agric. Food chem., vol. 40, pp. 1135-1138, 1992.

[9] X. C. Weng and M. H. Gordon, "Antioxidant activity of quinones extracted from tashen ( Salvia mitorrhiza Bunge)," J. Agric. Food chem., vol. 40, pp. 1331-1336, 1992.

[10] G. Miliauskas, P. Venskutonic, and T. A. Van, "Screening of radical scavenging activity of some medicinal and aromatic plant extracts," Food Chem., vol. 82, pp. 231-237, 2004.

[11] G. O. Adegoke, S. B. Fasoyiro, and B. J. Skura, "Control of microbial growth, browning and lipid oxidation by the spice Aframomum danielli," Eur. Food Res. Technol., vol. 211, pp. 342-345, 2001.

[12] S. B. Fasoyiro, G. O. Adegoke, V. A. Obatolu, O. Ashaye, and S. O. Aroyuen, "The antioxidant properties of Aframomum danielli in Oils," J. Food Technol. Africa, vol. 6, pp. 135-137, 2001.

[13] G. O. Adegoke and B. J. Skura, "Nutritional profile and antioxidant spectrum of the spice Aframomum danielli," Plant Food Human Nut., vol. 45, pp. 175-182, 1994.

[14] AOAC, Official Methods of Analysis (14th ed). Association of Official Analytical Chemists, Washington D. C, 14th ed. 1984

[15] J. W. Corrant, "Emulsion Technology and History of Mayonnaaise," Chem. Publ, vol. 50, 2003.

[16] J. Smith, "Food additives users handbook Glasgow: Academic Press," pp. 5-46, 1991.

[17] D. Pearson, The Chemical analysis of foods. New York: Chemical Publishing Company, 1991.

[18] G. O. Adegoke and A. G. Gopalakrishna, "Extraction and identification of antioxidants from the spice Aframomum danielli," J. Amer. Oil. Chem. Soc., vol. 75, pp. 1047-1052, 1998.

[19] A. Valenzuela and S. Nieto, "Natural and synthetic antioxidants: Food quality protectors," Grasas and Aceites, vol. 47, pp. 186-196, 1996.

[20] E. Beltran, R. Pla, J. Yutse, and M. Mor-mur, "Use of antioxidants to minimize rancidity in pressurized and cooked chicken slurries," Meat Science, vol. 66, pp. 719-725, 2004.

[21] J. Pokorny, "Natural antioxidants for food use," Trends Food Sci. Technol., vol. 2, pp. 223-227, 1991.

[22] L. L. Zaika, J. C. Kissinger, and A. E. Wesserma, "Inhibition of Lactic acid bacteria by herbs," J. Food Sci, vol. 48, pp. 1455-1459, 1983.

[23] O. I. Aruoma, "Extracts as antioxidant prophylactic agents," INFORM, vol. 8, pp. 1236-1242, 1997. 